IJßER

ISSN: 2149-5939
International Journal of Social Sciences and Education Research

Online, https://dergipark.org.tr/tr/pub/ijsser

Volume: 6(3), 2020

Research Article

\title{
Analysis of scientific production on strategic alliances in the period 1980- 2018
}

\author{
Sara Berka ${ }^{1}$ and Hicham Achelhi ${ }^{2}$
}

Received date: $16 / 05 / 2020$

Accepted date: 27 / 06 / 2020

\begin{abstract}
The objective of this study is to understand the scientific research conducted on strategic alliances and to explore the evolution of themes in this area over the period 1980-2018. It takes an integrated approach of quantitative and qualitative analyses to understand and analyze the scientific research published on strategic alliances between 1980 and 2018 in the Web of science database and to reveal the evolution of the themes addressed in this field. The quantitative study adopts bibliometric techniques based on citation and co-occurrence analyses of keywords. The qualitative study includes a content analysis of the articles carried out to discover the content of the most cited articles on strategic alliances. The results show that research on strategic alliances has evolved over the period 1980 and 2018 from a stream of research focused on the motivations for forming and structuring strategic alliances, from another stream focused on learning, performance and failure of strategic alliances to a new stream characterized by the emergence of new terms such as absorptive capacity with a strong emphasis on knowledge management and transfer within strategic alliances.
\end{abstract}

Keywords: Strategic alliance, citation analysis, co-occurrence analysis, content analysis

\section{Introduction}

Bibliometric or scientometric studies on the evolution of research topics in different fields are frequently published. Here are some typical examples: (Cole, 1917) had carried out a study of the literature, published between 1850 and 1860, on anatomy. In 1927, (Gross \& Gross, 1927) were the first to count the citations that researchers made in their own articles. In 1965, (Price, 1965) is considered one of the pioneers of the discipline by analyzing the scientific activity of the sociological component and according to sociological rules. These studies introduce quantitative, qualitative or combined dimensions to the measurement of science.

Bibliometric or quantitative studies are defined as the application of mathematical and statistical techniques to books and other media (Pritchard, 1969). More recently, (Archambault \& Gagné, s. d.) has proposed that bibliometrics consists of a variety of mathematical and statistical methods that allow for quantitative analyses of the sciences (Archambault \& Gagné, s. d.). Bibliometrics is therefore the use of a set of mathematical and statistical techniques that seek to analyze bibliographic references. These studies use a wide variety of techniques, the most important of which are based on citations, co-citations and co-occurrences.

The content analysis of the article, according to (Albig, 1952) is a technique for objective, systematic and quantitative description of the content of communications. According to (Paisley,

${ }^{1}$ CED Faculty of Legal, Economic and Social Sciences Laboratory of Management, Law and Social Changes, Abdelmalek Essaâdi University, Tangier, Morocco, saraberka10@gmail.com

${ }^{2}$ Prof. Dr., CED Faculty of Legal, Economic and Social Sciences Laboratory of Management, Law and Social Changes, Abdelmalek Essaâdi University, Tangier, Morocco, achelhihicham@gmail.com 
Berka, S., Achelhi, H. (2020). Analysis of scientific production on strategic alliances in the period 1980-2018. International Journal of Social Sciences and Education Research, 6(3), 396-412.

1989) bibliometrics focused on extrinsic facts about the publication of the article, the identification and affiliation of the author and the citation. While the intrinsic content of the article is considered to be the domain of content analysis, bibliometrics has focused on extrinsic facts about the publication of the article, author identification and affiliation, and citation (Paisley, 1989).

However, many studies have been conducted to review published research on strategic alliances. In 2010, (Moran, 2010) conducted a purely quantitative analysis of the scientific production on strategic alliances between 1989 and 2008 to identify the most cited authors, articles and journals. At the same date, (Lin \& Cheng, 2010) focused on co-citation analysis to describe the knowledge network accumulated on strategic alliances between 1999 and 2008. By 2014, (Ferreira et al., 2014) reviewed existing research on strategic alliances over a period of 1993 and 2012 using citation and co-citation analyses to identify the research themes addressed. As of the same date, (Gomes et al., 2016) conducted a literature review of strategic alliance research publications to identify the research methodology used in the most cited articles in major management journals between 1990 and 2012.

Despite the usefulness of these studies, they relied only on citations and joint citations (Ferreira et al., 2014) and they covered short periods of time that do not allow for specific trends to be identified (Lin \& Cheng, 2010). This article is seen as a response to suggestions from (Tsai-yuan lin, 2010) and (Manuel portugal ferreira, 2014). The objective is to combine quantitative and content methods to evaluate published research on strategic alliances over a period from 1980 to 2018.

The purpose of this article is to understand the scientific research conducted on strategic alliances and to explore the evolution of themes in this field over the period 1980-2018. Out of a total of 6900 published articles, we carried out two types of study: a quantitative study based on a citation and co-occurrence analysis and a qualitative analysis on the content of the most cited articles on strategic alliances.

The quantitative study adopts bibliometric techniques based on citation and co-occurrence analysis of keywords. Citation analysis was conducted to identify the most cited articles on strategic alliances in the Web of Science database. Keyword co-occurrence analysis was performed using the VOSviewer software used to identify the period and frequency of occurrence of keywords presented in the most influential articles in the strategic alliance field during the period 1980 and 2018.

The qualitative study includes a content analysis of the articles carried out to discover the content of the most cited articles on strategic alliances.

The article is organized as follows: presentation of the methodology used for this study, then the results of the quantitative and qualitative analyses are presented. Finally, a discussion of these studies and conclusions are proposed.

\section{Methods}

This study takes an integrated approach of quantitative and qualitative studies to analyze published research on strategic alliances. The data for this study was collected using the Web of science analysis database. The research on this database was done by theme, limiting the research period to between 1980 and 2018. This study is comprised of two essential steps: 
Berka, S., Achelhi, H. (2020). Analysis of scientific production on strategic alliances in the period 1980-2018. International Journal of Social Sciences and Education Research, 6(3), 396-412.

1st step: Quantitative study of the articles published on strategic alliances in the Web of science analysis database.

The quantitative study uses bibliometric techniques based on citation analysis and keyword co-occurrences. Citation analysis is based on the assumption that the most cited articles have a greater influence on a topic than the least cited articles (Sharplin \& Mabry, 1985). Citation analysis was used to identify the most influential articles in the strategic alliance field.

Keyword co-occurrence analysis is an analytical technique that uses the words in documents to construct a conceptual structure of the domain (Callon et al., 2016). Using the results of the citation analysis, we used VOSviewer 1.6.6 software to identify the period and frequency of occurrence of keywords in the most cited articles on strategic alliances over the period 1980 and 2018.

2nd step: Qualitative study of articles published on strategic alliances in the Web of science database during the period 1980 and 2018.

Based on the results of the citation analysis, the qualitative study based on a content analysis of the articles was carried out to discover the content of the most cited articles on strategic alliances.

\section{Results}

3.1. Quantitative study of articles published on strategic alliances during the period 1980 and 2018

\subsubsection{Citation analysis}

Table 1 shows the results obtained from the citation analysis of articles published on strategic alliances between 1980 and 2018 carried out by the Web of Science database. The columns show the year the article was published, the author, the source, the total number of citations during this period for each published article, and the average citation per year. The majority of highly cited articles in the period 1980 to 2018, and therefore the most relevant, were published between the years 1985 and 2009.

Table 1. The most cited articles on strategic alliances in the period 1980-2018 in WoS

\begin{tabular}{|c|l|c|c|}
\hline $\begin{array}{c}\text { Year of } \\
\text { publication }\end{array}$ & \multicolumn{1}{|c|}{ Articles } & $\begin{array}{c}\text { Number of } \\
\text { citations }\end{array}$ & Average \\
\hline 1996 & $\begin{array}{l}\text { Interorganizational collaboration and the locus of innovation: net- } \\
\text { works of learning in biotechnology, Powell, ww; Koput, Kw; } \\
\text { Smithdoerr, Administrative science quarterly }\end{array}$ & 3704 & 154.33 \\
\hline 2002 & $\begin{array}{l}\text { Absorptive capacity: a review, reconceptualization, and extension, } \\
\text { Zahra, Sa; George ; Academy of management review }\end{array}$ & 2980 & 175.29 \\
\hline 1991 & $\begin{array}{l}\text { Competition for competence and inter-partner learning within in- } \\
\text { ternational strategic alliances, Hamel, G; Strategic management } \\
\text { journal }\end{array}$ & 1962 & 67.66 \\
\hline 1998 & Alliances and networks; Gulati, r; Strategic management journal & 1913 & 86.95 \\
\hline 2000 & $\begin{array}{l}\text { Strategic networks; Gulati, r; Nohria, n; Aaheer, a; Strategic man- } \\
\text { agement journal }\end{array}$ & 1636 & 81.8 \\
\hline 2005 & $\begin{array}{l}\text { Social capital, networks, and knowledge transfer; Inkpen, ac; } \\
\text { tsang, ewk ; Academy of management review }\end{array}$ & 1517 & 101.13 \\
\hline 1996 & $\begin{array}{l}\text { Strategic alliances and interfirm knowledge transfer; Mowery, Dc; } \\
\text { Oxley, je; Silverman, Bs; Strategic management journal }\end{array}$ & 1486 & 61.92 \\
\hline
\end{tabular}

Copyright (C) by International Journal of Social Sciences and Education Research ISSN: 2149-5939 
Berka, S., Achelhi, H. (2020). Analysis of scientific production on strategic alliances in the period 1980-2018. International Journal of Social Sciences and Education Research, 6(3), 396-412.

\begin{tabular}{|c|c|c|c|}
\hline 1991 & $\begin{array}{l}\text { Competition for competence and inter-partner learning with inter- } \\
\text { national strategic alliances; Hamel, Gary; Strategic management } \\
\text { journal }\end{array}$ & 1445 & 72.88 \\
\hline 1998 & $\begin{array}{l}\text { Between trust and control: developing confidence in partner coop- } \\
\text { eration in alliances; Das, Tk; Teng, bs ; Academy of management } \\
\text { review }\end{array}$ & 1420 & 64.55 \\
\hline 1994 & $\begin{array}{l}\text { Characteristics of partnership success }- \text { partnership attributes, } \\
\text { communication behavior, and conflict-resolution techniques; } \\
\text { Mohr, j; Spekman, } r \text {; Strategic management journal }\end{array}$ & 1378 & 53 \\
\hline 2000 & $\begin{array}{l}\text { Learning and protection of proprietaryassets in strategic alliances: } \\
\text { building relational capital; Kale, p; Singh, h; Perlmutter; Strategic } \\
\text { management journal }\end{array}$ & 1291 & 64.55 \\
\hline 1992 & $\begin{array}{l}\text { Structuring cooperative relationships between organizations; Ring, } \\
\text { Ps; Vandeven; Strategic management journal }\end{array}$ & 1256 & 44.86 \\
\hline 1993 & $\begin{array}{l}\text { Strategic alliance structuring - a game-theoretic and transaction } \\
\text { cost examination of interfirm cooperation; Parkhe, A ; Academy of } \\
\text { management journal }\end{array}$ & 1255 & 46.48 \\
\hline 2000 & $\begin{array}{l}\text { Don't go it alone: alliance network composition and startups' per- } \\
\text { formance in Canadian biotechnology; Baum, Jac; Calabrese, T; } \\
\text { Silverman; Strategic management journal }\end{array}$ & 1223 & 61.15 \\
\hline 1995 & $\begin{array}{l}\text { Social structure and alliance formation patterns: a longitudinal } \\
\text { analysis ; Gulati, R ; Administrative science quarterly }\end{array}$ & 1190 & 47.6 \\
\hline 1999 & $\begin{array}{l}\text { Where do interorganizational networks come from?; Gulati, R; } \\
\text { Gargiulo ; American journal of sociology }\end{array}$ & 1179 & 56.14 \\
\hline 2003 & $\begin{array}{l}\text { The network paradigm in organizational research: a review and ty- } \\
\text { pology; Borgatti, Sp; Foster; Journal of management }\end{array}$ & 1173 & 69 \\
\hline 1999 & $\begin{array}{l}\text { Interorganizational endorsements and the performance of entrepre- } \\
\text { neurial ventures; Stuart, Te; Hoang, H; Hybels ; Administrative } \\
\text { science quarterly }\end{array}$ & 1167 & 55.57 \\
\hline 1999 & $\begin{array}{l}\text { Network location and learning: the influence of network resources } \\
\text { and firm capabilities on alliance formation; Gulati, R ; Strategic } \\
\text { management journal }\end{array}$ & 1135 & 54.05 \\
\hline 1996 & $\begin{array}{l}\text { Resource-based view of strategic alliance formation: strategic and } \\
\text { social effects in entrepreneurial firms; Eisenhardt, Km; Schoonho- } \\
\text { ven ; Organization science }\end{array}$ & 1131 & 47.13 \\
\hline 1998 & $\begin{array}{l}\text { The architecture of cooperation: managing coordination costs and } \\
\text { appropriation concerns in strategic alliances; Gulati, R; Singh ; Ad- } \\
\text { ministrative science quarterly }\end{array}$ & 1094 & 49.73 \\
\hline 2000 & $\begin{array}{l}\text { A Resource-based theory of strategic alliances; Das, Tk; Teng; } \\
\text { Journal of management }\end{array}$ & 1084 & 54.2 \\
\hline 2006 & $\begin{array}{l}\text { The reification of absorptive capacity: a critical review and rejuve- } \\
\text { nation of the construct; Lane, Peter j; Koka, Balaji r.; Pathak, } \\
\text { Seemantini ; Academy of management review }\end{array}$ & 1067 & 76.21 \\
\hline 1993 & $\begin{array}{l}\text { Understanding the rationale of strategic technology partnering - in- } \\
\text { terorganizational modes of cooperation and sectoral differences; } \\
\text { Hagedoorn ; Strategic management journal }\end{array}$ & 1039 & 38.48 \\
\hline 1996 & $\begin{array}{l}\text { The evolution of cooperation in strategic alliances: initial condi- } \\
\text { tions or learning processes?; Doz, Y1 ; Strategic management jour- } \\
\text { nal }\end{array}$ & 1016 & 42.33 \\
\hline 2004 & $\begin{array}{l}\text { Knowledge networks as channels and conduits: the effects of spill- } \\
\text { overs in the boston biotechnology community; Owen-Smith, J; } \\
\text { Powell; Organization science }\end{array}$ & 943 & 58.94 \\
\hline 2003 & $\begin{array}{l}\text { Network-based research in entrepreneurship - a critical review; } \\
\text { Hoang, H; Antoncic ; Journal of business venturing }\end{array}$ & 931 & 54.76 \\
\hline 2001 & $\begin{array}{l}\text { Absorptive capacity, learning, and performance in international } \\
\text { joint ventures; Lane, } \mathrm{Pj} \text {; Salk, Je; Iyles ; Strategic management } \\
\text { journal }\end{array}$ & 870 & 45.79 \\
\hline 2001 & $\begin{array}{l}\text { The internationalization and performance of smes: Lu, Jw; } \\
\text { Beamish; Strategic management journal }\end{array}$ & 843 & 44.37 \\
\hline
\end{tabular}


Berka, S., Achelhi, H. (2020). Analysis of scientific production on strategic alliances in the period 1980-2018. International Journal of Social Sciences and Education Research, 6(3), 396-412.

\begin{tabular}{|c|c|c|c|}
\hline 2001 & $\begin{array}{l}\text { Internal capabilities, external networks, and performance: a study } \\
\text { on technology-based ventures; Lee, C; Lee, K; Pennings; Strategic } \\
\text { management journal }\end{array}$ & 840 & 44.21 \\
\hline 2000 & $\begin{array}{l}\text { Interorganizational alliances and the performance of firms: a study } \\
\text { of growth and innovation rates in a high-technology industry; Stu- } \\
\text { art; Strategic management journal }\end{array}$ & 830 & 41.2 \\
\hline 2002 & $\begin{array}{l}\text { Alliance capability, stock market response, and long-term alliance } \\
\text { success: the role of the alliance function; Kale, P; Dyer, Jh; Singh; } \\
\text { Strategic management journal }\end{array}$ & 828 & 46 \\
\hline 2000 & $\begin{array}{l}\text { Do firms learn to create value? the case of alliances; Anand, Bn; } \\
\text { Khanna ; Strategic management journal }\end{array}$ & 816 & 40.8 \\
\hline 2006 & $\begin{array}{l}\text { The competitive advantage of interconnected firms: an extension } \\
\text { of the resource-based view; Lavie, Dovev; Academy of manage- } \\
\text { ment review }\end{array}$ & 789 & 56.36 \\
\hline 2002 & $\begin{array}{l}\text { Inter-firm r\&d partnerships: an overview of major trends and pat- } \\
\text { terns since 1960; Hagedoorn ; Research policy }\end{array}$ & 789 & 43.83 \\
\hline 2004 & $\begin{array}{l}\text { A knowledge accessing theory of strategic alliances; Grant, Rm; } \\
\text { Baden-Fuller; Journal of management studies }\end{array}$ & 777 & 48.56 \\
\hline 2001 & $\begin{array}{l}\text { Trust, control, and risk in strategic alliances: an integrated frame } \\
\text { work; Das, Tk; Teng ; Organization studies }\end{array}$ & 759 & 39.95 \\
\hline 2000 & $\begin{array}{l}\text { The duality of collaboration: inducements and opportunities in the } \\
\text { formation of interfirm linkages; Ahuja ; Strategic management } \\
\text { journal }\end{array}$ & 736 & 36.8 \\
\hline 1997 & $\begin{array}{l}\text { knowledge, bargaining power, and the instability of international } \\
\text { joint ventures; Inkpen, Ac; Beamish ; Academy of management re- } \\
\text { view }\end{array}$ & 733 & 31.87 \\
\hline 1994 & $\begin{array}{l}\text { Explaining the formation of international new ventures - the limits } \\
\text { of theories from international-business research; Mcdougall, Pp; } \\
\text { Shane, S; Oviatt; Journal of business venturing }\end{array}$ & 655 & 25.19 \\
\hline 1991 & $\begin{array}{l}\text { Interfirm diversity, organizational learning, and longevity in global } \\
\text { strategic alliances; Parkhe ; Journal of international business stud- } \\
\text { ies }\end{array}$ & 488 & 16.83 \\
\hline 2000 & $\begin{array}{l}\text { Instabilities of strategic alliances. an internal tensions perspective; } \\
\text { Das, Tk; Teng ; Organization science }\end{array}$ & 460 & 23 \\
\hline 1997 & $\begin{array}{l}\text { The importance of collaborative know-how: an empirical test of } \\
\text { the learning organization; Simonin; Academy of management } \\
\text { journal }\end{array}$ & 438 & 19.04 \\
\hline 1994 & $\begin{array}{l}\text { Developmental processes of cooperative interorganizational rela- } \\
\text { tionships ; Peter Smith Ring, Andrew h. van de ven ; The academy } \\
\text { of management review }\end{array}$ & 434 & 48.62 \\
\hline 2002 & $\begin{array}{l}\text { Interorganizational routines and performance in strategic alliances; } \\
\text { Zollo, M; Reuer, Jj; Singh, H; Organization science }\end{array}$ & 429 & 26.65 \\
\hline 2000 & $\begin{array}{l}\text { Learning from competing partners: outcomes and durations of } \\
\text { scale and link alliances in europe, north america and asia; } \\
\text { Dussauge, P; Garrette, B; Mitchell, W; Strategic management } \\
\text { journal }\end{array}$ & 350 & 18.42 \\
\hline 2002 & $\begin{array}{l}\text { Alliance-based competitive dynamics ; Silverman, Bs; Baum, Jac ; } \\
\text { Academy of management journal }\end{array}$ & 329 & 20.44 \\
\hline 1995 & $\begin{array}{l}\text { Determinants of success in international strategic alliances: evi- } \\
\text { dence from the global aerospace industry; Dussauge, Garrette ; So- } \\
\text { cial science \& medicine }\end{array}$ & 321 & 19.21 \\
\hline 2009 & $\begin{array}{l}\text { Managing strategic alliances: what do we know now, and where do } \\
\text { we go from here?; Kale,P Prashant; Singh, Harbir; Academy of } \\
\text { management perspectives }\end{array}$ & 274 & 20.23 \\
\hline 2000 & $\begin{array}{l}\text { Redundant governance structures: an analysis of structural and re- } \\
\text { lational embeddedness in the steel and semiconductor industries; } \\
\text { Rowley, T; Behrens, D; Krackhardt; Strategic management journal }\end{array}$ & 272 & 19.02 \\
\hline
\end{tabular}


Berka, S., Achelhi, H. (2020). Analysis of scientific production on strategic alliances in the period 1980-2018. International Journal of Social Sciences and Education Research, 6(3), 396-412.

As shown in Table 1, the publication dates of the most cited articles range from 1991 to 2009. These articles were published primarily in 15 journals. The first journal in this ranking is Strategic Management Journal. Its alone accounts for $42 \%$ of the most cited articles, with 21 articles out of 50. The first four journals in this ranking account for $70 \%$ of the cited articles. These journals are: Strategic Management Journal, Academy of Management Review, Administrative Science Quarterly and Organization science. These top four journals are American journals. Eight of the 15 journals (53.3\% of the journals) present one article among the 50 most cited articles. The detailed results are presented in Table 2.

Table 2. Number of articles per journal

\begin{tabular}{|l|c|c|}
\hline \multicolumn{1}{|c|}{ Sources } & Number of articles & Origin \\
\hline Strategic Management Journal & 21 & USA \\
\hline Academy of Management Review & 6 & USA \\
\hline Administrative Science Quarterly & 4 & USA \\
\hline Organization science & 4 & USA \\
\hline Academy of Management Journal & 3 & USA \\
\hline Journal of Business Venture & 2 & USA \\
\hline Journal of Management & 2 & USA \\
\hline Academy of Management Perspective & 1 & USA \\
\hline American Journal of Sociology & 1 & USA \\
\hline Journal of international business studies & 1 & UK \\
\hline Journal of management Studies & 1 & USA \\
\hline Organization studies & 1 & Denmark \\
\hline Research Policy & 1 & UK \\
\hline Social Science and Medicine & 1 & UK \\
\hline The Academy of Management Review & 1 & USA \\
\hline
\end{tabular}

These journals focus on the concept of strategic alliances in the fields of business economics, management science and engineering. The origin of the journals : $92 \%$ of the most cited articles are published in American journals, $6 \%$ of British origin and 2\% of Danish origin.

\subsubsection{Co-occurrence analysis}

The application of the VOSviewer software identified four clusters of high-frequency keywords that appeared more than 20 times in the first 50 most cited articles on strategic alliances over the period 1980 and 2018 in the Web of Science database shown in Figure1.

The first cluster represents the period between 1980 and 1995 presented in red and includes 8 key words, namely cooperation, forms, governance, alliances, collaboration, social networks, $\mathrm{R} \& \mathrm{D}$ and strategic alliance formation.

The second cluster belongs to the period between 1994 and 2002 and is presented in green and includes 6 keywords, namely determinants, international joint ventures, joint ventures, knowledge, performance and trust.

The third cluster presented in yellow groups the only keyword, is knowledge transfer represents the period from 2002 to 2004.

The fourth cluster represents the period between 2002 and 2009 presented in blue displays 5 key words which are: strategic alliances, joint ventures, social structure, learning and absorptive capacity. 
Berka, S., Achelhi, H. (2020). Analysis of scientific production on strategic alliances in the period 1980-2018. International Journal of Social Sciences and Education Research, 6(3), 396-412.

Figure 1. Analysis of co-occurrences during the period 1980-2018 of the first 50 most cited articles on strategic alliances (cluster view)

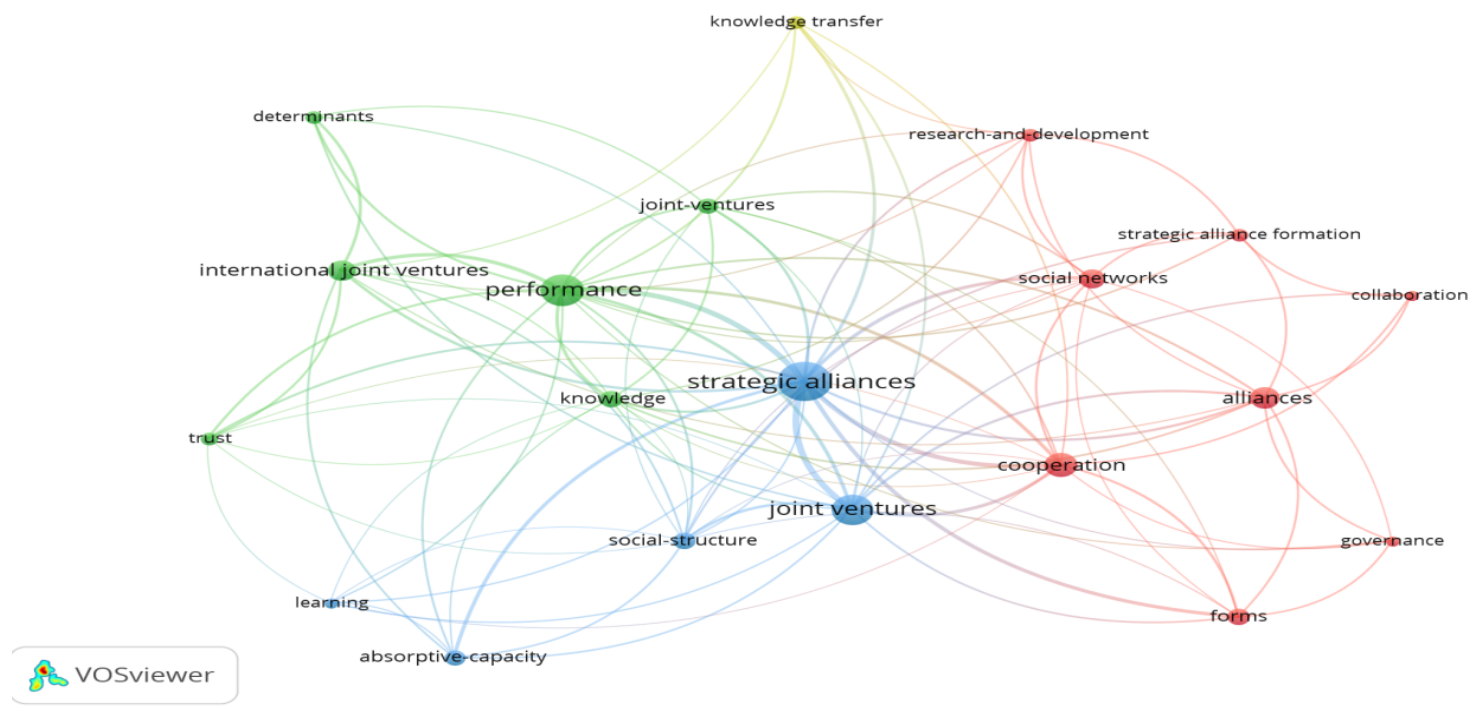

The result of the co-occurrence analysis of the keywords appearing in the first 50 most cited articles on strategic alliances allowed us to identify four periods between 1980 and 2018. These periods end in 2009. This can be explained by the fact that the first 50 highly cited articles on strategic alliances were published between 1991 and 2009.

To complete this analysis, and in order to identify the most frequent keywords starting in 2009, we performed the same analysis on the first 100 most cited articles published on strategic alliances during the period 1980- 2018.

The results of the analysis allowed us to identify six clusters of high-frequency keywords that appeared more than 15 occurrences in the first 100 most cited articles on strategic alliances over the period 1980 and 2018 in the Web of Science database presented in Figure 2.

The first cluster represents the period between 1980 and 1995 presented in blue and includes 5 key words, namely forms, governance, alliances, social networks and strategic alliance formation.

The second cluster belongs to the period between 1994 and 2002 and is shown in yellow. It consists of 5 keywords, namely determinants, international joint ventures, performance, cooperation and strategic alliance.

The third cluster represents the period from 2002 to 2004, presented in green and includes 5 key words which are : knowledge transfer, strategic alliance, learning, trust and collaboration.

Cluster 4 represents the period between 2004 and 2006 presented in sky blue displays 2 key words which are : absorptive capacity and knowledge transfer.

Cluster 5, shown in purple, represents the period between 2006 and 2009. It displays 3 key words: knowledge, exploration and exploitation.

Cluster 6 belongs to the period between 2009 and 2014 presented in red and includes 5 key words which are: social structure, joint venture, portfolio, exploration and exploitation and absorptive capacity. 
Berka, S., Achelhi, H. (2020). Analysis of scientific production on strategic alliances in the period 1980-2018.

International Journal of Social Sciences and Education Research, 6(3), 396-412.

Figure 2. Analysis of co-occurrences during the period 1980-2018 of the first 100 most cited articles on strategic alliances (cluster view)

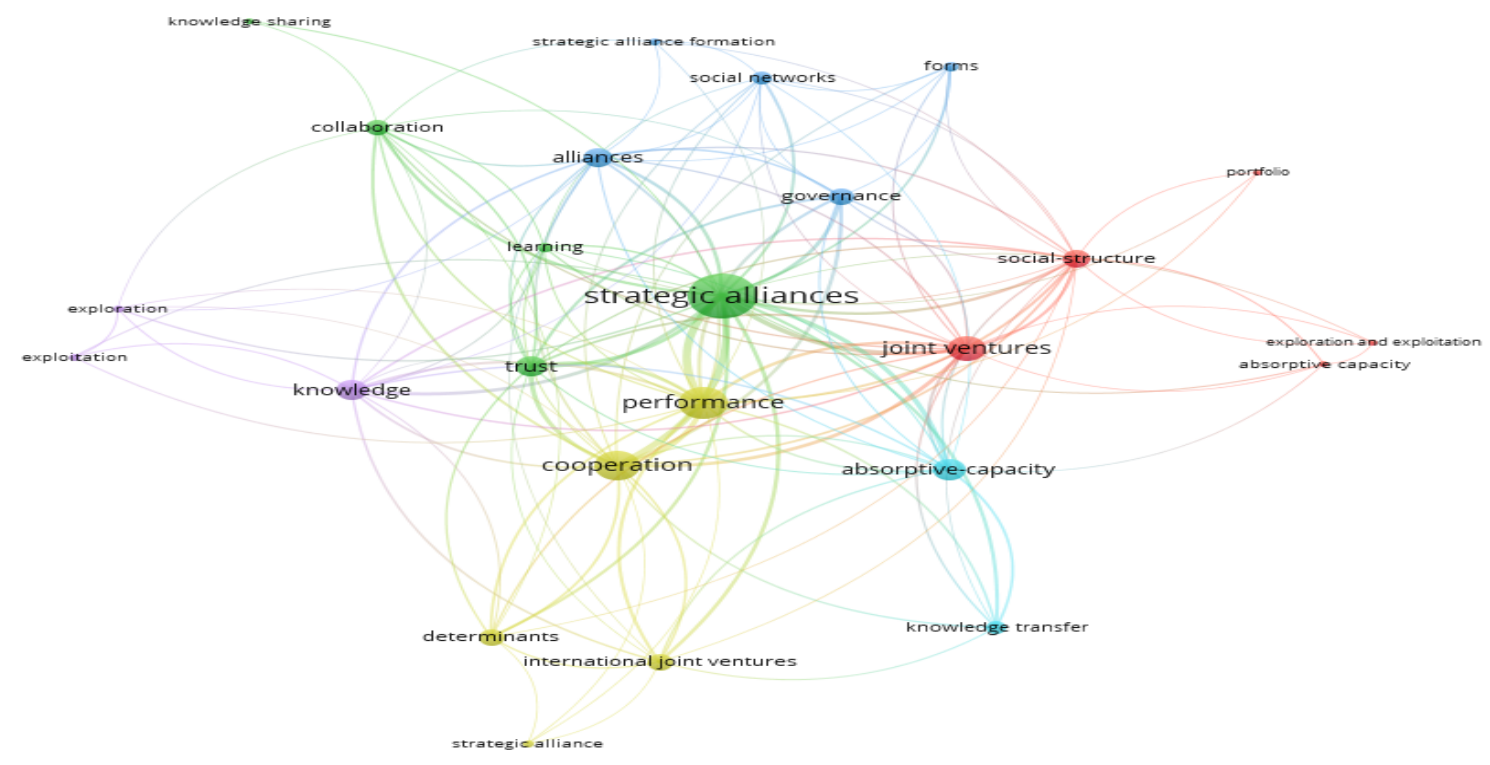

\subsection{Qualitative study of the main articles published on strategic alliances during the period 1980} and 2018

This analysis was carried out to identify the content of the most cited articles on strategic alliances. It was based on the first 50 most cited articles on strategic alliances during the period 1980 and 2018. The choice of these articles is linked to their high number of citations and the long period during which the articles remained cited. The results are presented in Table 3 .

Table 3. The research objects of the first 50 most cited articles on strategic alliances

\begin{tabular}{|l|l|}
\hline \multicolumn{1}{|c|}{ Articles } & \multicolumn{1}{c|}{ Research subject } \\
\hline $\begin{array}{l}\text { Interorganizational collabora- } \\
\text { tion and the locus of innova- } \\
\text { tion: networks of learning in } \\
\text { biotechnology }\end{array}$ & $\begin{array}{l}\text { He argues that collaborative networks provide access to resources and } \\
\text { skills that are not generated internally or obtained through market } \\
\text { transactions. He tests the link between learning and business perfor- } \\
\text { mance within an r\&d alliance and links them to collaborative experi- } \\
\text { ence, management of relationships within the network, the partner's } \\
\text { position within the network, and portfolios of collaborative activities }\end{array}$ \\
\hline $\begin{array}{l}\text { Absorptive capacity: a review, } \\
\text { reconceptualization, and ex- } \\
\text { tension }\end{array}$ & $\begin{array}{l}\text { It reviews the key dimensions of absorptive capacity and proposes a } \\
\text { conceptualization of this concept based on the dynamic vision of the } \\
\text { company's capabilities. }\end{array}$ \\
\hline $\begin{array}{l}\text { Competition for competence } \\
\text { and inter-partner learning } \\
\text { within international strategic } \\
\text { alliances }\end{array}$ & $\begin{array}{l}\text { This article shows the role of collaboration in the distribution of com- } \\
\text { petencies among partners. It aims to understand the impact of intent, } \\
\text { transparency and responsiveness on learning outcomes. }\end{array}$ \\
\hline Alliances and networks & $\begin{array}{l}\text { It demonstrates how social networks from previous links can be used } \\
\text { to discover new alliances, influence the choice of governance structure } \\
\text { used to formalize the alliance and their path, and affect the success of } \\
\text { the alliance. }\end{array}$ \\
\hline Strategic networks & $\begin{array}{l}\text { The objective of this article is to show the influence of strategic net- } \\
\text { works on the performance of allied companies by identifying the role } \\
\text { of five key issues which are: industry concentration, the position of the } \\
\text { partner in the network, access to key resources, reduction of }\end{array}$ \\
\hline
\end{tabular}


Berka, S., Achelhi, H. (2020). Analysis of scientific production on strategic alliances in the period 1980-2018. International Journal of Social Sciences and Education Research, 6(3), 396-412.

\begin{tabular}{|c|c|}
\hline & $\begin{array}{l}\text { coordination and contracting costs and finally the consequences of } \\
\text { learning on the economic performance of the allied company }\end{array}$ \\
\hline $\begin{array}{l}\text { Social capital, networks, and } \\
\text { knowledge transfer }\end{array}$ & $\begin{array}{l}\text { It proposes a set of conditions that promote knowledge transfer for dif- } \\
\text { ferent types of corporate networks. It explains how the social capital } \\
\text { of networks affects the transfer of knowledge and information between } \\
\text { network members due to membership in social networks along } 3 \text { di- } \\
\text { mensions: structural, cognitive and relational. }\end{array}$ \\
\hline $\begin{array}{l}\text { Strategic alliances and inter- } \\
\text { firm knowledge transfer }\end{array}$ & $\begin{array}{l}\text { Use of citation models of companies' patent portfolios to measure the } \\
\text { effects of participation in strategic alliances on companies' technolog- } \\
\text { ical capabilities. }\end{array}$ \\
\hline $\begin{array}{l}\text { Between trust and control: de- } \\
\text { veloping confidence in partner } \\
\text { cooperation in alliances }\end{array}$ & $\begin{array}{l}\text { This article examines the concept of trust, identifies the sources and } \\
\text { suggests ways to build trust within a strategic alliance. }\end{array}$ \\
\hline $\begin{array}{l}\text { Characteristics of partnership } \\
\text { success - partnership attrib- } \\
\text { utes, communication behavior, } \\
\text { and conflict-resolution tech- } \\
\text { niques }\end{array}$ & $\begin{array}{l}\text { It examines the requirements for forming vertical partnerships with an } \\
\text { understanding of the characteristics associated with the success of a } \\
\text { partnership such as the attributes of commitment, coordination and } \\
\text { trust; the quality of communication and participation; and the conflict } \\
\text { resolution technique of joint problem solving. }\end{array}$ \\
\hline $\begin{array}{l}\text { Learning and protection of pro- } \\
\text { prietary assets in strategic alli- } \\
\text { ances: building relational capi- } \\
\text { tal }\end{array}$ & $\begin{array}{l}\text { It suggests that building relational capital based on trust and an inte- } \\
\text { grative approach to conflict management can help companies to strike } \\
\text { a balance between acquiring new capabilities and protecting their own } \\
\text { assets and limit the opportunism of partners in an alliance situation. }\end{array}$ \\
\hline $\begin{array}{l}\text { Structuring cooperative rela- } \\
\text { tionships between organiza- } \\
\text { tions }\end{array}$ & $\begin{array}{l}\text { It examines the characteristics of recurring and relational contracts and } \\
\text { the influence of trust and risk on the choice of form of governance. }\end{array}$ \\
\hline $\begin{array}{l}\text { Strategic alliance structuring - } \\
\text { a game-theoretic and transac- } \\
\text { tion cost examination of inter- } \\
\text { firm cooperation }\end{array}$ & $\begin{array}{l}\text { It proposes an incentive model of alliance structuring combined with } \\
\text { game theory and transaction cost economics logics identified by } 3 \\
\text { structural dimensions }\end{array}$ \\
\hline $\begin{array}{l}\text { Don't go it alone: alliance net- } \\
\text { work composition and startups' } \\
\text { performance in Canadian bio- } \\
\text { technology }\end{array}$ & $\begin{array}{l}\text { This article presents the impact of the diversity and composition of } \\
\text { startups' strategic alliance networks providing access to social, tech- } \\
\text { nical and business resources on their initial performance as measured } \\
\text { by multiple performance measures. }\end{array}$ \\
\hline $\begin{array}{l}\text { Social structure and alliance } \\
\text { formation patterns: a longitudi- } \\
\text { nal analysis }\end{array}$ & $\begin{array}{l}\text { It explains the formation of alliances in a social structure made up of } \\
\text { direct and indirect links that allows companies to learn about the reli- } \\
\text { ability and capacities of current and potential partners, guide alliance } \\
\text { decisions, create reputation channels and build a basis of trust between } \\
\text { partners. }\end{array}$ \\
\hline $\begin{array}{l}\text { Where do interorganizational } \\
\text { networks come from? }\end{array}$ & $\begin{array}{l}\text { It has developed a model to identify the decision-making mechanisms } \\
\text { of partner selection composed of endogenous and exogenous factors. }\end{array}$ \\
\hline $\begin{array}{l}\text { The network paradigm in or- } \\
\text { ganizational research: A re- } \\
\text { view and typology }\end{array}$ & $\begin{array}{l}\text { This article proposes a classification of networked research by propos- } \\
\text { ing a typology that cross-references the studies according to mecha- } \\
\text { nisms, levels of analysis, styles and explanatory objectives }\end{array}$ \\
\hline $\begin{array}{l}\text { Interorganizational endorse- } \\
\text { ments and the performance of } \\
\text { entrepreneurial ventures }\end{array}$ & $\begin{array}{l}\text { It examines how the inter-organizational networks of start-ups affect } \\
\text { their ability to acquire the resources they need to survive. They found } \\
\text { that the initial public offering performance of start-ups was influenced } \\
\text { by the technological and commercial importance of their partners. }\end{array}$ \\
\hline $\begin{array}{l}\text { Network location and learning: } \\
\text { the influence of network re- } \\
\text { sources and firm capabilities } \\
\text { on alliance formation }\end{array}$ & $\begin{array}{l}\text { It shows the importance of the information resources of the network of } \\
\text { past alliances and factors based on firms' alliance-forming capabilities. }\end{array}$ \\
\hline $\begin{array}{l}\text { Resource-based view of strate- } \\
\text { gic alliance formation: strate- } \\
\text { gic and social effects in entre- } \\
\text { preneurial firms }\end{array}$ & $\begin{array}{l}\text { The article explains the logic of forming alliances based on needs and } \\
\text { opportunities. It suggests that companies form alliances when they } \\
\text { need the additional resources that alliances can provide or when they } \\
\text { are in a strong social position so that they have the resources to attract } \\
\text { and encourage partners. }\end{array}$ \\
\hline
\end{tabular}

Copyright $(\mathcal{C}$ by International Journal of Social Sciences and Education Research

ISSN: 2149-5939 
Berka, S., Achelhi, H. (2020). Analysis of scientific production on strategic alliances in the period 1980-2018. International Journal of Social Sciences and Education Research, 6(3), 396-412.

\begin{tabular}{|c|c|}
\hline $\begin{array}{l}\text { The architecture of coopera- } \\
\text { tion: managing coordination } \\
\text { costs and appropriation con- } \\
\text { cerns in strategic alliances }\end{array}$ & $\begin{array}{l}\text { It shows the influence of coordination costs and ownership concerns } \\
\text { on determining the structure used to formalize alliances. }\end{array}$ \\
\hline $\begin{array}{l}\text { A resource-based theory of } \\
\text { strategic alliances }\end{array}$ & $\begin{array}{l}\text { Developed a comprehensive and integrated theory of strategic alli- } \\
\text { ances from a resource perspective that examines the role of resources } \\
\text { in strategic alliance formation, structure and performance. }\end{array}$ \\
\hline $\begin{array}{l}\text { The reification of absorptive } \\
\text { capacity: a critical review and } \\
\text { rejuvenation of the construct }\end{array}$ & $\begin{array}{l}\text { It provides a detailed analysis of the use of absorptive capacity con- } \\
\text { cepts and proposes a model of absorptive capacity processes, anteced- } \\
\text { ents and results. }\end{array}$ \\
\hline $\begin{array}{l}\text { Understanding the rationale of } \\
\text { strategic technology partnering } \\
\text { - interorganizational modes of } \\
\text { cooperation and sectoral dif- } \\
\text { ferences }\end{array}$ & $\begin{array}{l}\text { It presents an assessment of the diversity of motivations for strategic } \\
\text { technology cooperation and the influence of sectoral differences and } \\
\text { organizational governance patterns on the motivations of firms to co- } \\
\text { operate. }\end{array}$ \\
\hline $\begin{array}{l}\text { The evolution of cooperation } \\
\text { in strategic alliances: initial } \\
\text { conditions or learning pro- } \\
\text { cesses? }\end{array}$ & $\begin{array}{l}\text { It examines the learning within alliances mediates between the initial } \\
\text { conditions and outcomes of alliances. It suggests that the success of an } \\
\text { alliance is in the setting of initial conditions and a cycle of learning, } \\
\text { reevaluation and readjustment. }\end{array}$ \\
\hline $\begin{array}{l}\text { Knowledge networks as chan- } \\
\text { nels and conduits: the effects } \\
\text { of spillovers in the Boston bio- } \\
\text { technology community }\end{array}$ & $\begin{array}{l}\text { It considered formal alliances as channels for the dissemination of in- } \\
\text { formation or as exclusive channels for the transfer of information and } \\
\text { resources between partners. It examined the relationship between the } \\
\text { geographic location of organizations linked by formal ties and the in- } \\
\text { stitutional characteristics of network members on the changing char- } \\
\text { acter of information flows }\end{array}$ \\
\hline $\begin{array}{l}\text { Network-based research in en- } \\
\text { trepreneurship - a critical re- } \\
\text { view }\end{array}$ & $\begin{array}{l}\text { The article provides a perspective on network-based entrepreneurship. } \\
\text { It presents a summary of the components that seek to explain the pro- } \\
\text { cess of network development during entrepreneurial activity presented } \\
\text { in a body of work on networks in order to identify potential avenues } \\
\text { for future research. }\end{array}$ \\
\hline $\begin{array}{l}\text { Absorptive capacity, learning, } \\
\text { and performance in interna- } \\
\text { tional joint ventures }\end{array}$ & $\begin{array}{l}\text { The article shows the role of absorptive capacity in inter-organiza- } \\
\text { tional learning and performance and the factors that influence a jvi's } \\
\text { ability to understand, assimilate and apply knowledge. }\end{array}$ \\
\hline $\begin{array}{l}\text { The internationalization and } \\
\text { performance of smes }\end{array}$ & $\begin{array}{l}\text { The link between the scale of foreign investment and export activity } \\
\text { and the use of strategic alliances. }\end{array}$ \\
\hline $\begin{array}{l}\text { Internal capabilities, external } \\
\text { networks, and performance: a } \\
\text { study on technology-based } \\
\text { ventures }\end{array}$ & $\begin{array}{l}\text { It shows the influence of internal capabilities and social networks on } \\
\text { the performance of start-up companies. }\end{array}$ \\
\hline $\begin{array}{l}\text { Interorganizational alliances } \\
\text { and the performance of firms: } \\
\text { a study of growth and innova- } \\
\text { tion rates in a high-technology } \\
\text { industry }\end{array}$ & $\begin{array}{l}\text { It examines the importance of partner profile characteristics within } \\
\text { technology alliances on company performance. It argues that alliances } \\
\text { with large and innovative strategic partners perform best on two vari- } \\
\text { ables: the rate of innovation and the rate of growth. }\end{array}$ \\
\hline $\begin{array}{l}\text { Alliance capability, stock mar- } \\
\text { ket response, and long-term al- } \\
\text { liance success: the role of the } \\
\text { alliance function }\end{array}$ & $\begin{array}{l}\text { He presented the influence of the alliance experience and a dedicated } \\
\text { alliance function on the success of alliances. }\end{array}$ \\
\hline $\begin{array}{l}\text { Do firms learn to create value? } \\
\text { the case of alliances }\end{array}$ & It shows the effects of learning on value creation through alliances. \\
\hline $\begin{array}{l}\text { The competitive advantage of } \\
\text { interconnected firms: an exten- } \\
\text { sion of the resource-based } \\
\text { view }\end{array}$ & $\begin{array}{l}\text { The paper provides a theoretical analysis of the competitive advantage } \\
\text { of firms participating in alliances. It suggests that the resources of al- } \\
\text { liance partners transferred through direct firm-to-firm interaction in- } \\
\text { fluence firm performance. }\end{array}$ \\
\hline $\begin{array}{l}\text { Inter-firm r\&d partnerships: an } \\
\text { overview of major trends and } \\
\text { patterns since } 1960\end{array}$ & $\begin{array}{l}\text { It presents historical and sectoral trends in R\&D partnerships from the } \\
1960 \text { s to the } 1990 \mathrm{~s} \text {. }\end{array}$ \\
\hline
\end{tabular}


Berka, S., Achelhi, H. (2020). Analysis of scientific production on strategic alliances in the period 1980-2018. International Journal of Social Sciences and Education Research, 6(3), 396-412.

\begin{tabular}{|c|c|}
\hline $\begin{array}{l}\text { A knowledge accessing theory } \\
\text { of strategic alliances }\end{array}$ & $\begin{array}{l}\text { It explains the distinction between the exploration and exploitation of } \\
\text { knowledge. It shows the contribution of alliances to production effi- } \\
\text { ciency by increasing the stock of knowledge and the application of } \\
\text { knowledge to create value. }\end{array}$ \\
\hline $\begin{array}{l}\text { Trust, control, and risk in stra- } \\
\text { tegic alliances: an integrated } \\
\text { framework }\end{array}$ & $\begin{array}{l}\text { This paper examines the interrelationships between trust, control and } \\
\text { risk in different typologies of strategic alliances. }\end{array}$ \\
\hline $\begin{array}{l}\text { The duality of collaboration: } \\
\text { inducements and opportunities } \\
\text { in the formation of interfirm } \\
\text { linkages }\end{array}$ & $\begin{array}{l}\text { His paper shows the influence of firm capital on the incentives to form } \\
\text { firm ties }\end{array}$ \\
\hline $\begin{array}{l}\text { Knowledge, bargaining power, } \\
\text { and the instability of interna- } \\
\text { tional joint ventures }\end{array}$ & $\begin{array}{l}\text { The paper develops a theoretical model of ijv instability that results } \\
\text { from changes in the bargaining power associated with the acquisition } \\
\text { of knowledge and skills that allow for the elimination of partner de- } \\
\text { pendency and the changing need for cooperation. }\end{array}$ \\
\hline $\begin{array}{l}\text { Explaining the formation of in- } \\
\text { ternational new ventures - the } \\
\text { limits of theories from interna- } \\
\text { tional-business research }\end{array}$ & $\begin{array}{l}\text { He explains the importance of hybrid structures for new international } \\
\text { companies. He suggests that they need to rely on alliances to overcome } \\
\text { the usual resource poverty at start-up. }\end{array}$ \\
\hline $\begin{array}{l}\text { Interfirm diversity, organiza- } \\
\text { tional learning, and longevity } \\
\text { in global strategic alliances }\end{array}$ & $\begin{array}{l}\text { The article shows the impact of the diversity of partner characteristics } \\
\text { on the emergence and maintenance of an alliance relationship through } \\
\text { a process of organizational learning and adaptation. }\end{array}$ \\
\hline $\begin{array}{l}\text { Instabilities of strategic alli- } \\
\text { ances. an internal tensions per- } \\
\text { spective }\end{array}$ & $\begin{array}{l}\text { It proposes a global framework for understanding the instabilities of } \\
\text { alliances based on internal tensions and their impacts on different types } \\
\text { of strategic alliances with an explanation of the intrinsic vulnerability } \\
\text { of alliances in terms of internal contradictions. }\end{array}$ \\
\hline $\begin{array}{l}\text { The importance of collabora- } \\
\text { tive know-how: an empirical } \\
\text { test of the learning organiza- } \\
\text { tion }\end{array}$ & $\begin{array}{l}\text { The article shows the importance of collaborative know-how on alli- } \\
\text { ance performance. It suggests that companies learn from past relation- } \\
\text { ships by acquiring skills to identify potential partners, negotiate the } \\
\text { form of collaboration, manage and monitor collaboration and know } \\
\text { when to end it. }\end{array}$ \\
\hline $\begin{array}{l}\text { Developmental processes of } \\
\text { cooperative interorganiza- } \\
\text { tional relationships }\end{array}$ & $\begin{array}{l}\text { It examines the process of development and evolution of strategic al- } \\
\text { liance relationships. }\end{array}$ \\
\hline $\begin{array}{l}\text { Interorganizational routines } \\
\text { and performance in strategic } \\
\text { alliances }\end{array}$ & $\begin{array}{l}\text { It examines the role of coordination and organizational routines for } \\
\text { cooperation in improving the effectiveness and efficiency of the coop- } \\
\text { eration agreement in the biotechnology industry. }\end{array}$ \\
\hline $\begin{array}{l}\text { Learning from competing part- } \\
\text { ners: outcomes and durations } \\
\text { of scale and link alliances in } \\
\text { Europe, north America and } \\
\text { Asia }\end{array}$ & $\begin{array}{l}\text { It examines the outcomes of strategic alliances between competitors as } \\
\text { an indicator of partner firm learning. It argues that transfer and learn- } \\
\text { ing often occurs in linkage alliances rather than scale alliances. }\end{array}$ \\
\hline $\begin{array}{l}\text { Alliance-based competitive } \\
\text { dynamics }\end{array}$ & $\begin{array}{l}\text { The degree to which alliances of horizontal, upstream and downstream } \\
\text { rivals may increase or decrease competitive pressure between compet- } \\
\text { ing firms. }\end{array}$ \\
\hline $\begin{array}{l}\text { Determinants of success in in- } \\
\text { ternational strategic alliances: } \\
\text { evidence from the global aero- } \\
\text { space industry }\end{array}$ & $\begin{array}{l}\text { It tests differences in the levels of economic performance achieved in } \\
\text { different types of alliances of competing partner companies. }\end{array}$ \\
\hline $\begin{array}{l}\text { Managing strategic alliances: } \\
\text { what do we know now, and } \\
\text { where do we go from here? }\end{array}$ & $\begin{array}{l}\text { Identification of strategic alliance performance factors during all } \\
\text { phases of the life cycle of an alliance }\end{array}$ \\
\hline $\begin{array}{l}\text { Redundant governance struc- } \\
\text { tures: an analysis of structural } \\
\text { and relational embeddedness } \\
\text { in the steel and semiconductor } \\
\text { industries }\end{array}$ & $\begin{array}{l}\text { It identifies the sources of competitive advantage in the inter-organi- } \\
\text { zational domain by studying the influence of relational and structural } \\
\text { integration on business performance. }\end{array}$ \\
\hline
\end{tabular}

Copyright (C) by International Journal of Social Sciences and Education Research

ISSN: 2149-5939 
Berka, S., Achelhi, H. (2020). Analysis of scientific production on strategic alliances in the period 1980-2018.

International Journal of Social Sciences and Education Research, 6(3), 396-412.

\section{Discussion}

Based on these results, we define three periods of analysis of strategic alliance research between 1980 and 2018.

Strategic alliances in the period 1980-1995:

Research on strategic alliances during this period was characterized by a slow growth in publications, focused on the ex-ante phase of the alliance. A high frequency of occurrence of the words form, governance and strategic alliance formation was marked in this period. Studies have focused on the motives for creating alliances and the structuring of alliances. The trend that attempts to explain the reasons for the creation of alliances suggests three factors: transaction and production costs (Williamson, 1985) strategic (Hagedoorn, 1993) and learning (Hamel et al., 1989b; Hamel, 1991). The structuring of alliances occupies an important place in the literature on strategic alliances during the period 1988 and 1994. Studies have explained the structural implications (Parkhe, 1993), sectoral (characteristics of demand and competitors) (Harrigan, 1988) and the impact of levels of risk and trust on the choice of form of governance (Ring \& van de Ven, 1992).

Social networks occupy an important place in the literature, with a large occurrence in early 1995. Researchers have begun to examine the role of social networks in alliance formation and partner selection (Gulati, 1995).

Strategic alliances in the period 1995-2002:

The evolution of research during this period is characterized by a rapid and unstable growth of publications on strategic alliances, marked by a high occurrence of the word's performance, determinants, learning and trust. This instability may be due to high rates of alliance failure and instability. This stream seeks both to identify the determinants of performance and the reasons for alliance failure and instability. In the early $1990 \mathrm{~s}$, research tended to focus on identifying the factors associated with strategic alliance success (Das \& Teng, 2000b; Gulati, 1998; Gulati et al., 2000; Mohr \& Spekman, 1994; Ring \& van de Ven, 1994). Other researchers have tried to explain the reasons for instability and alliance failure (Inkpen \& Beamish, 1997) and (Das \& Teng, 2000).

In the late 1989 's, researchers began to focus on learning as the main reason for alliance formation (Hamel et al., 1989). The 1990s saw a high occurrence of the word learning of several types. Many researchers see learning in strategic alliances as access to the skills and capacities of partners (Hamel et al., 1989; Hamel, 1991; Kale et al., 2000; Powell et al., 1996). While others also referred to the learning process in which partners learn to manage the alliance (B. Anand \& Khanna, 2000; Doz, 1996; Kale et al., 2002; Simonin, 1997). This period is marked by a high occurrence of the word's JV and JVI. This high frequency is due to the international trend in partnerships (Hagedoorn, 2002; Lane et al., 2001; Phillips et al., 1994) and the high rates of instability in JVs and JVIs (Hagedoorn, 2002; Inkpen \& Beamish, 1997).

The contribution of researchers related to the notion of trust has been important. Studies have focused on the impact of trust on the performance of the alliance (Das \& Teng, 1998; Mohr \& Spekman, 1994) the reduced likelihood of JVI instability; and (Inkpen \& Beamish, 1997) the choice of governance (Ring \& van de Ven, 1992) a response to the problems of coordination and ownership (Gulati \& Singh, 1998) and as a mode of social control between the parties (Ring \& van de Ven, 1992). 
Berka, S., Achelhi, H. (2020). Analysis of scientific production on strategic alliances in the period 1980-2018. International Journal of Social Sciences and Education Research, 6(3), 396-412.

The formation of strategic alliances remains a theme that is more or less addressed with less frequency than in the previous period. Researchers have increasingly drawn attention to social and strategic integration in the formation of strategic alliances (Ahuja, 2000; Brown \& Eisenhardt, 1997; Gulati \& Gargiulo, 1999). While others have begun to focus more attention on the importance of alliance building for start-ups and SMEs. (Baum et al., 2000; Lee et al., 2001; Phillips et al., 1994; Stuart et al., 1999) suggest that new enterprises (international and/or national) tend to use alliances to access the complementary and necessary resources to survive and overcome resource limitations that threaten the expansion of an SME (Lu \& Beamish, 2001).

Strategic alliances in the period 2002-2018:

This period is characterized by an intensive growth in strategic alliance publications, with the rise in publications peaking in 2016.

At the beginning of 2001, the search is marked by the appearance of new terms such as absorption capacity, exploitation and exploration. Researchers began to focus on the factors that influence JVIs' ability to understand, assimilate and apply knowledge connaissances (Lane et al., 2001) knowledge sharing and integration (Zahra \& George, 2002) and the ability to create new knowledge (Lane et al., 2006). Knowledge management and transfer became a key area of research in the strategic alliance literature during the period 2002-2018 (Grant \& Baden-Fuller, 2004; Inkpen \& Tsang, 2005; Owen-Smith \& Powell, 2004).

Performance remains a topical issue due to the high failure rate of strategic alliances (Kale \& Singh, 2009; Lane et al., 2006).

During this period, researchers continued to retain more of the development results and impacts of networks in the process of creating new businesses or on small and medium-sized enterprises and family businesses (Hoang \& Antoncic, 2003). While others have drawn attention to the management of strategic alliance portfolios.

\section{Conclusion}

This study is considered a response to suggestions from (Lin \& Cheng, 2010) and (Ferreira et al., 2014). An integrated approach of quantitative and qualitative methods was conducted to analyse the level of knowledge accumulated on strategic alliances over the period 1980 and 2018 in the Web of Science database.

The quantitative study adopts bibliometric techniques based on citation and co-occurrence analysis of keywords. Citation analysis was conducted to identify the most cited articles on strategic alliances during the period 1980 and 2018 in the Web of science database. Keyword cooccurrence analysis was performed using VOSviewer 1.6.6 software to identify the period and frequency of occurrence of keywords in the articles.

The qualitative study includes a content analysis of the most cited articles on strategic alliances over the period 1980 and 2018. Its objective is to discover the content of the most cited articles on strategic alliances in order to identify the research themes addressed and their evolution.

This work has shown that research on strategic alliances has evolved over the period 1980 and 2018, moving from a stream of research focused on the motivations for forming and structuring strategic alliances in the period 1980-1995, from another stream focused on the learning, performance and failure of strategic alliances in the period 1995 and 2001 to a new stream characterized

Copyright (C) by International Journal of Social Sciences and Education Research 
Berka, S., Achelhi, H. (2020). Analysis of scientific production on strategic alliances in the period 1980-2018. International Journal of Social Sciences and Education Research, 6(3), 396-412.

by the emergence of new terms such as absorptive capacity with a strong emphasis on the management and transfer of knowledge within strategic alliances. The results thus showed that some themes experienced an increase in popularity during the period 1980 and 2018, while others experienced a decline.

The formation of strategic alliances remains the most discussed theme throughout the analysis period, characterized by a change in the reasons and incentives for forming strategic alliances. Researchers have consistently demonstrated the importance of strategic alliance formation in reducing transaction and production costs (Williamson, 1985) learning (Hamel et al., 1989; Hamel, 1991), technological complementarity and market access (Hagedoorn, 1993) access to resources and expertise (Baum et al., 2000; Das \& Teng, 2000; Powell et al., 1996) the creation of new direct and indirect links (Gulati, 1998, 1999) access to strategic needs and social opportunities (Ahuja, 2000; Eisenhardt \& Schoonhoven, 1996; Gulati \& Gargiulo, 1999) access to the complementary resources necessary for the survival of SMEs and national and/or international start-ups (Lu \& Beamish, 2001; Phillips et al., 1994; Stuart et al., 1999) and entrepreneurial activities (Hoang \& Antoncic, 2003).

Research on the performance and instability of strategic alliances has remained a topical issue since the early 1990s (Das \& Teng, 2000a, 2000b; Gulati, 1998; Gulati et al., 2000; Inkpen \& Beamish, 1997; Mohr \& Spekman, 1994; Ring \& van de Ven, 1994). Until the end of 2009, researchers are still identifying the factors and determinants of the performance of strategic alliances (Kale \& Singh, 2009; Lane et al., 2006).

The theme of structuring strategic alliances, which dominated the first period between 1980 and 1995, has declined. Whereas, the importance was given to the notion of trust and social networks within strategic alliances throughout the period 1980-2018.

Research on learning within strategic alliances was strong during the first two periods of analysis. In the early 1989 's, researchers began to focus on learning as a motive for alliance formation (Hamel et al., 1989a). Over time, researchers have begun to distinguish between types of learning in strategic alliance situations strategies (B. Anand \& Khanna, 2000; Doz, 1996; Hamel et al., 1989; Hamel, 1991; Inkpen \& Tsang, 2005; Kale et al., 2000, 2002; Powell et al., 1996; Simonin, 1997). Starting in the 2000s, researchers began to pay more attention to the importance of the dedicated alliance function as a new type of learning within strategic alliances (B. N. Anand \& Khanna, 2000; Kale et al., 2002). The third phase of analysis, covering the period 2002-2018, was marked by the emergence of new terms such as absorptive capacity, management and knowledge transfer. Research on learning has been replaced by absorptive capacity, which allows firms to learn how to create new knowledge as opposed to learning how to improve what they already do. Researchers are beginning to focus on the ability of firms to understand, assimilate and apply knowledge (Lane et al., 2001) knowledge sharing and integration (Zahra \& George, 2002) the ability to create new knowledge (Peter J. lane, 2006) and knowledge management and transfer (Grant \& Baden-Fuller, 2004; Inkpen \& Tsang, 2005; Owen-Smith \& Powell, 2004).

This study makes several contributions to the current literature. First, it is seen as a channel for identifying the most relevant articles in the field of strategic alliances and accessing their content. In this way, it allows us to understand the published literature on strategic alliances and to determine the direction of future research. 
Berka, S., Achelhi, H. (2020). Analysis of scientific production on strategic alliances in the period 1980-2018. International Journal of Social Sciences and Education Research, 6(3), 396-412.

Despite the contributions of this study, it has some limitations that are worth examining. The first concerns the choice of the key word 'strategic alliance', which may leave other articles dealing with other forms and typologies of corporate relationships. Second, the analysis was made on the most relevant articles in the field to understand the evolution of published research on strategic alliances. The most cited articles appear to be older articles published between the years 1985 and 2009. Evaluation of recently published articles may yield different results. It is suggested that the study on the analysis of the published literature on strategic alliances be continued with a greater focus on citation and co-citation networks in order to know the context in which they are made.

\section{References}

Ahuja, G. (2000). The duality of collaboration: inducements and opportunities in the formation of interfirm linkages. 27.

Albig,W. (1952). Berelson, bernard. Content analysis in communication research. The annals of the american academy of political and social science, 283(1), 197-198.

Anand, B., \& Khanna, T. (2000). Do firms learn to create value ? The case of alliances. Strategic management journal, 21, 295-315.

Archambault, E., \& Gagné, E. V. (s. D.). The use of bibliometrics in the social sciences and humanities. Final report, 79 .

Baum, J. A. C., Calabrese, T., \& Silverman, B. S. (2000). Don't go it alone : alliance network composition and startups' performance in canadian biotechnology. Strategic management journal, 21(3), 267-294.

Brown, S. L., \& Eisenhardt, K. M. (1997). The art of continuous change : linking complexity theory and time-paced evolution in relentlessly shifting organizations. Administrative science quarterly, $42(1), 1$.

Callon, M., Courtial, J.-P., Turner, W. A., \& Bauin, S. (2016). From translations to problematic networks : an introduction to co-word analysis : social science information.

Cole, F. J., \& Nellie B. (1917). The history of comparative anatomy : a statistical analysis of the literature. Science progress (1916-1919), 11(44), 578-596.

Das, T. K., \& Teng, B. S. (1998). Between trust and control : developing confidence in partner cooperation in alliances. The academy of management review, 23(3), 491.

Das, T. K., \& Teng, B. S. (2000a). A resource-based theory of strategic alliances. Journal of management, 26(1), 31-61.

Das, T. K., \& Teng, B. S. (2000b). Instabilities of strategic alliances : an internal tensions perspective. Organization science, 11(1), 77-101.

Doz, Y. L. (1996). The evolution of cooperation in strategic alliances : initial conditions or learning processes ? Strategic management journal, 17, 55-83.

Eisenhardt, K. M., \& Schoonhoven, C. B. (1996). Resource-based view of strategic alliance formation : strategic and social effects in entrepreneurial firms. Organization science, 7(2), 136-150.

Ferreira, M. P., Storopoli, J. E., \& Serra, F. R. (2014). Two decades of research on strategic alliances : analysis of citations, co-citations and themes researched. Revista de administração contemporânea, 18(spe), 109-133.

Gomes, E., Barnes, B. R., \& Mahmood, T. (2016). A 22 year review of strategic alliance research in the leading management journals. International business review, 25(1), 15-27.

Grant, R. M., \& Baden-Fuller, C. (2004). A knowledge accessing theory of strategic alliances. Journal of management studies, 41(1), 61-84.

Gross, P. L. K., \& Gross, E. M. (1927). College libraries and chemical education. Science, 66(1713), 385-389.

Copyright (C) by International Journal of Social Sciences and Education Research ISSN: 2149-5939 
Berka, S., Achelhi, H. (2020). Analysis of scientific production on strategic alliances in the period 1980-2018. International Journal of Social Sciences and Education Research, 6(3), 396-412.

Gulati, R. (1995). Social structure and alliance formation patterns : a longitudinal analysis. Administrative science quarterly, 40(4), 619.

Gulati, R. (1998a). Alliances and networks. Strategic management journal, 19(4), 293-317.

Gulati, R. (1999). Network location and learning : the influence of network resources and firm capabilities on alliance formation. Strategic management journal, 20(5), 397-420.

Gulati, R., \& Gargiulo, M. (1999). Where do interorganizational networks come from? American journal of sociology, 104(5), 1439-1493.

Gulati, R., Nohria, N., \& Zaheer, A. (2000). Strategic networks. Strategic management journal, 21(3), 203-215.

Gulati, R., \& Singh, H. (1998). The architecture of cooperation : managing coordination costs and appropriation concerns in strategic alliances. Administrative science quarterly, 43(4), 781.

Hagedoorn, J. (1993). Understanding the rationale of strategic technology partnering : interorganizational modes of cooperation and sectoral differences. Strategic management journal, 14(5), 371-385.

Hagedoorn, J. (2002). Inter-firm r\&d partnerships : an overview of major trends and patterns since 1960. Research policy, 31(4), 477-492.

Hamel, G. (1991). Competition for competence and inter-partner learning within international strategic alliances. Strategic management journal, 12, 83-103.

Hamel, G., Doz, Y., \& Prahalad, C. K. (1989b). Collaborate with your competitors - and win. Harvard business review.

Harrigan, K. R. (1988). Joint ventures and competitive strategy. Strategic management journal, 9(2), 141-158.

Hoang, H., \& Antoncic, B. (2003). Network-based research in entrepreneurship. Journal of business venturing, 18(2), 165-187.

Inkpen, A. C., \& Beamish, P. W. (1997). Knowledge, bargaining power, and the instability of international joint ventures. The academy of management review, 22(1), 177.

Inkpen, A. C., \& Tsang, E. W. K. (2005). Social capital, networks, and knowledge transfer. The academy of management review, 30(1), 146-165.

Kale, P., Dyer, J. H., \& Singh, H. (2002). Alliance capability, stock market response, and long-term alliance success : the role of the alliance function. Strategic management journal, 23(8), 747-767.

Kale, P., \& Singh, H. (2009). Managing strategic alliances : what do we know now, and where do we go from here ? Academy of management perspectives, 23(3), 45-62.

Kale, P., Singh, H., \& Perlmutter, H. (2000). Learning and protection of proprietary assets in strategic alliances : building relational capital. 21.

Lane, P. J., Koka, B. R., \& Pathak, S. (2006). The reification of absorptive capacity : a critical review and rejuvenation of the construct. Academy of management review, 31(4), 833-863.

Lane, P. J., Salk, J. E., \& Lyles, M. A. (2001). Absorptive capacity, learning, and performance in international joint ventures. Strategic management journal, 22(12), 1139-1161.

Lee, C., Lee, K., \& Pennings, J. M. (2001). Internal capabilities, external networks, and performance : a study on technology-based ventures. Strategic management journal, 22(6-7), 615-640.

Lin, T.Y., \& Cheng, Y. Y. (2010). Exploring the knowledge network of strategic alliance research: a cocitation analysis. $8(2), 9$.

Lu, J. W., \& Beamish, P. W. (2001). The internationalization and performance of smes. Strategic management journal, 22(6-7), 565-586.

Mohr, J., \& Spekman, R. (1994). Characteristics of partnership success : partnership attributes, communication behavior, and conflict resolution techniques. Strategic management journal, 15(2), 135-152. 
Berka, S., Achelhi, H. (2020). Analysis of scientific production on strategic alliances in the period 1980-2018. International Journal of Social Sciences and Education Research, 6(3), 396-412.

Moran, M. R. (2010). Alianças estratégicas : uma análise bibliométrica da produção científica entre 1989 e 2008. Revista de ciências da administração, 12(27), 23.

Owen-Smith, J., \& Powell, W. W. (2004). Knowledge networks as channels and conduits : the effects of spillovers in the boston biotechnology community. Organization science, 15(1), 5-21.

Paisley, W. (1989). Bibliometrics, scholarly communication, and communication research. Communication research, 16(5), 701-717.

Parkhe, A. (1993). Strategic alliance structuring: a game theoretic and transaction cost examination of interfirm cooperation. Academy of management journal, 36(4), 794-829.

Phillips, P., Shane, S., \& Oviatt, B. M. (1994). Explaining the formation of international new ventures : the limits of theories from international business research. Journal of business venturing, 9(6), 469-487.

Powell, W. W., Koput, K. W., \& Smith-Doerr, L. (1996). Interorganizational collaboration and the locus of innovation : networks of learning in biotechnology. Administrative science quarterly, 41(1), 116.

Price, D. J. De S. (1965). Networks of scientific papers. Science, 149(3683), 510-515.

Pritchard, A. E. (1969). Statistical bibliography or bibliometrics.

Ring, P. S., \& Van De Ven, A. H. (1992). Structuring cooperative relationships between organizations. Strategic management journal, 13(7), 483-498.

Ring, P. S., \& Van De Ven, A. H. (1994). Developmental processes of cooperative interorganizational relationships. The academy of management review, 19(1), 90.

Sharplin, A. D., \& Mabry, R. H. (1985). The relative importance of journals used in management research : an alternative ranking. Human relations, 38(2), 139-149.

Simonin, B. L. (1997). The importance of collaborative know-how : an empirical test of the learning organization. Academy of management journal, 40(5), 1150-1174.

Stuart, T. E., Hoang, H., \& Hybels, R. C. (1999). Interorganizational endorsements and the performance of entrepreneurial ventures. Administrative science quarterly, 44(2), 315-349.

Williamson, O. E. (1985). The economic intstitutions of capitalism. Simon and schuster.

Zahra, S. A., \& George, G. (2002). Absorptive capacity : a review, reconceptualization, and extension. The academy of management review, 27(2), 185.

Copyright (C) by International Journal of Social Sciences and Education Research ISSN: 2149-5939 